\title{
Sea urchin Tetrapygus niger distribution on elevated surfaces represents a strategy for avoiding predatory sea stars
}

\author{
Juan Diego Urriago ${ }^{1,2,3}$, John H. Himmelman ${ }^{1}$, Carlos F. Gaymer ${ }^{2, *}$ \\ ${ }^{1}$ Département de Biologie, Université Laval, Québec City, Québec, Canada G1V 0A6 \\ ${ }^{2}$ Departamento de Biología Marina and Centro de Estudios Avanzados en Zonas Áridas (CEAZA), \\ Universidad Católica del Norte, Casilla 117, Coquimbo, Chile \\ ${ }^{3}$ Present address: Department of Biology, Hong Kong Baptist University, Swire Institute of Marine Science, \\ Cape d'Aguilar Road, Shek O, Hong Kong SAR
}

\begin{abstract}
We ran field experiments to examine whether the micro-distribution of the sea urchin Tetrapygus niger on elevated surfaces represents a strategy for limiting predation by the sea stars Heliaster helianthus and Meyenaster gelatinosus. Several lines of evidence supported this hypothesis. (1) A survey of the distribution of the urchin and the 2 sea stars showed that urchins occur mainly on elevated surfaces, and sea stars on low surfaces. (2) In trials involving simulated attacks, the time needed by the urchin to sever contact with the sea stars was $48 \%$ less on elevated surfaces than on the bottom. (3) In trials involving sustained simulated attacks (high predatory risk) the urchins could detach themselves from the elevated surfaces to avoid being eaten. Finally, tethering experiments indicated that the urchin had a higher survival rate on elevated than low surfaces. Our observations indicate that $M$. gelatinosus represents a stronger predatory threat to T. niger than $H$. helianthus.
\end{abstract}

KEY WORDS: Tetrapygus niger $\cdot$ Heliaster helianthus $\cdot$ Meyenaster gelatinosus $\cdot$ Predator-prey interactions · Aggregation · Distribution · Tethering

Resale or republication not permitted without written consent of the publisher

\section{INTRODUCTION}

Animals have a variety of anti-predatory strategies (Sih et al. 1985, Chivers \& Smith 1998, Ruxton et al. 2004, Caro 2005) that can be divided into 2 main categories: (1) avoiding encounters with predators and (2) avoiding being eaten once there has been an encounter (Lima \& Dill 1990). For example, the aposematic coloration of the poison frog Dendrobates pumilio decreases the probability of encounters with predators (Saporito et al. 2006) and autotomizing arms by the sea star Heliaster helianthus when under attack by the sea star Meyenaster gelatinosus decreases the probability of death (Gaymer \& Himmelman 2008). Predators not only affect prey directly by eating them, but also indirectly by changing their behaviour. Bottom structures, such as crevices, can reduce the probability of encounter with predators and thus increase survival. For several species of sea urchins, the juveniles hide in crevices to reduce the probability of predatory attack (Scheibling \& Hamm 1991, Rodriguez \& Ojeda 1993, Hereu et al. 2005). For the sea urchin Evechinus chloroticus, predatory mortality is most intense during the period when juveniles begin to leave crevices for open habitats (Shears \& Babcock 2002).

Sea urchins are important grazers in benthic communities. Locations supporting high densities of urchins are often transformed into barrens with a reduced diversity and biomass of macroalgae (Himmelman et al. 1983, McClanahan \& Shafir 1990, Alcoverro \& Mariani 2002, Shears \& Babcock 2002). 
Predators can affect the density, behaviour and population structure of urchins (Tegner \& Levin 1983, Sala et al. 1998, Tuya et al. 2004, Guidetti 2006). A variety of predators feed on urchins, including sea otters (Estes et al. 1998), fishes (Sala 1997), lobsters (Andrew \& MacDiarmid 1991), crabs (Scheibling \& Hamm 1991) and sea stars (Himmelman \& Dutil 1991). Relationships between sea stars and urchins are the best-studied of these interactions (Jensen 1966, Rosenthal \& Chess 1972, Dayton et al. 1977, Moitoza \& Phillips 1979, Legault \& Himmelman 1993, Rodriguez \& Ojeda 1998, Hagen et al. 2002).

The black sea urchin Tetrapygus niger is the most abundant urchin in central and northern Chile and it can attain a density of up to 40 ind. $\mathrm{m}^{2}$ (Vasquez \& Buschmann 1997). Its grazing has converted many subtidal areas into barrens. It usually limits the depth distribution of the subtidal kelp Lessonia trabeculata to shallow water and has caused local extinctions of the subtidal kelp Macrocystis integrifolia (Vega et al. 2005). A number of predators consume T. niger, including the fishes Semicossyphus maculatus (Fuentes 1981), Graus nigra (Fuentes 1982), Pinguipes chilensis (Rodriguez \& Ojeda 1998), Cheilodactylus variegatus, and Oplegnathus insignis (Medina et al. 2004) and the sea star Luidia magellanica (Gaymer \& Himmelman 2008). However, the predators likely to have the greatest impact on the abundance of $T$. niger are the sea stars Heliaster helianthus and Meyenaster gelatinosus (Barrios et al. 2008, Gaymer \& Himmelman 2008). These sea stars are keystone predators in shallow rocky communities in northern Chile (Gaymer \& Himmelman 2008, Barahona \& Navarrete 2010). $H$. helianthus is a generalist feeder consuming prey according to their availability (Gaymer \& Himmelman 2008, Barahona \& Navarrete 2010), whereas M. gelatinosus is a selective feeder that prefers consuming the urchin T. niger (Gaymer \& Himmelman 2008). Both $H$. helianthus and $M$. gelatinosus are endemic to the west coast of South America and reach average densities of 3 ind. $\mathrm{m}^{2}$ and $<0.5$ ind. $\mathrm{m}^{2}$, respectively, in northern Chile (Dayton et al. 1977, Tokeshi et al. 1989, Gaymer \& Himmelman 2008, Navarrete \& Manzur 2008). H. helianthus has a robust and flattened body with as many as 40 arms and can attain up to $32 \mathrm{~cm}$ in diameter (Tokeshi et al. 1989). In contrast, M. gelatinosus has a soft body with 6 thick arms and can attain $56 \mathrm{~cm}$ in diameter (Dayton et al. 1977, Gaymer \& Himmelman 2008).

Three studies have examined the behavioural responses of Tetrapygus niger to its sea star predators. T. niger can detect Meyenaster gelatinosus at a distance and responds rapidly by fleeing (Dayton et al.
1977). Under laboratory conditions, the urchin increased its rate of displacement in the presence of $M$. gelatinosus or the predatory fish Pinguipes chilensis and a higher proportion of individuals responded in trials with $M$. gelatinosus (92\%) than with $P$. chilensis (67\%) (Rodriguez \& Ojeda 1998). Finally, Urriago et al. (2011) showed that the urchin could differentiate between predatory (Heliaster helianthus and $M$. gelatinosus) and non-predatory (Stichaster striatus) sea stars, could distinguish between different threat levels associated with predatory sea stars and could detect predatory sea stars at a distance. They indicated that $M$. gelatinosus presented a stronger predatory threat to urchins than $H$. helianthus.

Tetrapygus niger frequently occur on elevated surfaces (e.g. boulder tops) within the barrens communities that predominate in shallow rocky subtidal areas along the coast of central and northern Chile. As food resources are less abundant on elevated surfaces than on the bottom, we reasoned that this microdistribution of $T$. niger might represent a strategy to limit attacks by the sea stars Heliaster helianthus and Meyenaster gelatinosus. The present study examines this hypothesis. We first documented the preference of the urchin for elevated surfaces, then examined the urchin's responses to sea stars in a variety of situations (predatory attacks), and finally conducted a tethering experiment to compare the survival on high and low surfaces (i.e. boulder tops vs. sea bottom).

\section{MATERIALS AND METHODS}

Our study was conducted during June, July and August in 2008 and 2009 in the subtidal zone at Obispito Bay $\left(26^{\circ} 48^{\prime} 22^{\prime \prime} \mathrm{S}, 70^{\circ} 47^{\prime} 5^{\prime \prime} \mathrm{W}\right)$, Cisnes Bay $\left(27^{\circ} 14^{\prime} 50^{\prime \prime} \mathrm{S}, 70^{\circ} 57^{\prime} 34^{\prime \prime} \mathrm{W}\right)$ and El Francés Bay $\left(30^{\circ} 5^{\prime} 42^{\prime \prime} \mathrm{S}, 71^{\circ} 22^{\prime} 47^{\prime \prime} \mathrm{W}\right)$ in northern Chile. All manipulations were made using SCUBA diving at depths of 2 to $9 \mathrm{~m}$ in wave-exposed environments (i.e. with continuous back and forth water movement). In all 3 bays, the bottom was moderately sloped (down to $\sim 10 \mathrm{~m}$ depth at $\sim 30 \mathrm{~m}$ from shore) and supported a barrens community. The sea urchin Tetrapygus niger was abundant ( 20 ind. $\left.\mathrm{m}^{2}\right)$ and the sea stars Heliaster helianthus and Meyenaster gelatinosus were present in much lower numbers $(<1.5$ and $<1$ ind. $\mathrm{m}^{2}$, respectively) (Gaymer \& Himmelman 2008). During our trials, water temperatures ranged between 12 and $14^{\circ} \mathrm{C}$. In the various experiments, the sea stars were taken at random from among individuals that were stationary and not feeding. Different urchins and sea stars were used in each trial. 


\section{Distribution of sea urchins and sea stars}

We conducted field surveys at Obispito, Cisnes and El Francés Bays to characterize the abundance and distribution of Tetrapygus niger and the 2 predatory sea stars Heliaster helianthus and Meyenaster gelatinosus. For each urchin and each sea star encountered we recorded its position in 2 categories, high and low surfaces. We also quantified the percentage cover of high and low surfaces. High surfaces included from the tops of boulders and bedrock outcrops to half way down the vertical faces of the structures, and low surfaces were flat areas of pebbles, shell debris and small cobbles as well as surfaces extending half way up the sides of boulders and outcrops. The boulders were 1.0 to $1.5 \mathrm{~m}$ in height and the outcrops 4 to $5 \mathrm{~m}$. In 2008 , we systematically surveyed an entire cove at Cisnes Bay (using five $50 \mathrm{~m}$ transects running from the shore seaward, and spaced at $6 \mathrm{~m}$ intervals) whereas in 2009 we sampled 79 randomly placed $1 \mathrm{~m}^{2}$ quadrats at Obispito Bay and 72 quadrats at El Francés Bay.

We placed predatory sea stars on boulder tops to determine whether they would remain there or move to lower positions. In each trial we placed a sea star on a boulder top not covered by sea urchins and held it there until it attached ( $<1 \mathrm{~min})$. Then, after $5 \mathrm{~min}$ we recorded its position. We ran 20 trials for both Meyenaster gelatinosus and Heliaster helianthus at El Francés Bay in 2009.

\section{Responses of sea urchins to sea stars on different types of bottom}

We further performed a number of short-term field experiments at Cisnes Bay in 2009 to provide insights into the responses of the sea urchin to the 2 predatory sea stars, Heliaster helianthus (9 to $14 \mathrm{~cm}$ in radius) and Meyenaster gelatinosus (13 to $21 \mathrm{~cm}$ ), on 3 types of bottom. We first quantified the time it took isolated urchins $(5$ to $6 \mathrm{~cm}$ in diameter and at least $20 \mathrm{~cm}$ from other urchins) to sever contact from a simulated attack by a sea star. A simulated attack consisted of holding a sea star so that an arm, or several arms in the case of $H$. helianthus, covered half of the target urchin. The sea star was maintained in the initial position relative to the substratum even as the urchin moved away. In each trial on each type of bottom we first placed an urchin on the substratum and allowed it 4 to 5 min to attach (this was done because urchins were rarely found on irregular horizontal surfaces). The urchins always remained very close to where they were placed. Then we initiated the simulated attack. We executed 20 simulated attacks with both $H$. helianthus and M. gelatinosus (1) on irregular horizontal bottoms, (2) on relatively smooth horizontal platforms (bedrock with few surface irregularities), and (3) on relatively smooth vertical walls (side of a bedrock outcrop or large boulder).

\section{Sustained (simulated) attacks on vertical walls}

We further ran experiments at Cisnes Bay in 2008 to examine the responses of undisturbed sea urchins to a sustained simulated attack (hereafter referred to as 'sustained attack') by predatory sea stars on vertical walls. In each trial we first selected a target urchin at the lower edge of an aggregation at the top of a wall. The walls were 4 to $5 \mathrm{~m}$ in height and the distance between the target urchin and the aggregation at the top varied from 50 to $80 \mathrm{~cm}$. We then initiated the sustained attack from below the urchin and advanced the sea star so that its arm (or several arms with Heliaster helianthus) always covered half the urchin. Each trial lasted until the urchin detached or reached the aggregation at the top of the wall. We executed 20 trials with both $H$. helianthus and Meyenaster gelatinosus.

\section{Sustained attacks on aggregations}

We also examined the behaviour of aggregations of urchins (5 to 23 individuals) on boulder tops to sustained attacks by predatory sea stars. In each trial we held a sea star so that it covered about half of an urchin at the edge of the aggregation. If this urchin moved, we continued to hold the sea star over it, and if it detached, we continued by attacking the next urchin in the same way. In all trials the aggregation started moving away from the sea star shortly after we initiated the first sustained attack. We continued with this procedure until all the urchins had (1) detached, (2) moved half-way down and then to the side (around the boulder), or (3) moved to the bottom. When no urchins were on top of the boulder, we removed the sea star. Then after $3 \mathrm{~min}$ we recorded the numbers of urchins that (1) continued to flee, (2) climbed up a boulder (the same boulder or a nearby boulder), or (3) remained stationary on the bottom. Preliminary trials showed that 3 min was long enough for an urchin to return to a boulder top. We executed 15 trials with both Meyenaster gelatinosus and Heliaster helianthus at Cisnes Bay in 2009. Each trial was on a different boulder and with a different sea star. 


\section{Survival on high and low surfaces}

In 2008 at Cisnes Bay we performed trials with tethered sea urchins on boulder tops, and on the bottom around boulders, to estimate the probability of survival in these 2 contrasting positions. The state of the each tethered sea urchin was assessed after $24 \mathrm{~h}$, and when possible the predators causing mortalities were identified, from direct observations or from prey remains. In both high and low positions, we ran 11 trials with small urchins ( 15 to $20 \mathrm{~mm}$ in diameter) and 11 with large urchins ( 50 to $60 \mathrm{~mm}$ ). The urchins were attached to the center of $20 \times 20 \mathrm{~cm}$ ceramic tiles with monofilament threads (the threads went over the urchin and through 6 holes that were drilled through the tiles). In the trials in high positions the tiles were attached to the boulders with Permalite sea-goin epoxy putty, whereas in the trials at low positions, rocks were placed at the edge of the tiles to hold them on the bottom.

\section{Statistical analyses}

To evaluate whether distribution of the sea urchin Tetrapygus niger and the 2 sea stars Heliaster helianthus and Meyenaster gelatinosus on high and low surfaces corresponded to the availability of these surfaces, we used 2 procedures. We applied a $\chi^{2}$ test using the adjusted residuals to identify specific differences between observed and expected values for each type of habitat (high and low surfaces), to evaluate the data from the systematic survey at Cisnes Bay, and the SURVEYMEANS procedure to evaluate the data from the random quadrat sampling at Obispito and El Francés Bays.

We used a 2-way ANOVA to compare the mean time that urchins took to sever contact with sea stars in the trials on the 3 types of bottom. In this model there were 2 fixed factors, predator species (Heliaster helianthus and Meyenaster gelatinosus) and type of bottom (irregular horizontal bottoms, smooth horizontal bottoms and vertical walls). The data were log-transformed to meet the assumptions of normality and homogeneity of variance, which were tested using Shapiro-Wilk's and Levene tests, respectively (Snedecor \& Cochran 1989). Pairwise comparisons were performed using protected Fisher least square difference tests (LSD).

For the experiments evaluating the behavioural responses of urchins aggregated on boulder tops, we compared the trials with sustained attacks by the 2 sea stars (Heliaster helianthus and Meyenaster gelatinosus) for the proportion of urchins (1) detaching, (2) moving down and then to the side and (3) moving to the bottom. We also compared the trials with the 2 sea stars for the proportion of urchins (1) continuing to flee, (2) climbing up a boulder and (3) remaining stationary on the bottom, 3 min after the sea stars were removed. A multinomial regression model was used for both analyses (using the LOGISTIC procedure with the glogit link).

Finally, a generalized linear model (using the GENMOD procedure with the binomial distribution and the logit link) was used to compare the proportion of small and large tethered urchins that survived on high and low surfaces. In this model there were 2 fixed factors, the position (high and low) and the size of the urchins (small and large). All statistical tests were performed using the software SAS v9.2 (SAS Institute 2008).

\section{RESULTS}

\section{Distribution of sea urchins and sea stars}

There was a similar availability of high and low surfaces at Cisnes Bay (about $50 \%$ for each), whereas high surfaces predominated at Obispito Bay $(81 \%)$ and El Francés Bay (72\%). At all 3 bays, most sea urchins Tetrapygus niger were found on high surfaces $(98 \%$ at Cisnes, $99 \%$ at Obispito and $67 \%$ at El Francés). In contrast, the predatory sea stars Heliaster helianthus and Meyenaster gelatinosus were more common on low surfaces, except for $H$. helianthus at Obispito Bay where only $33 \%$ were found on low surfaces $(p=0.20)$. The scarcity of low surfaces at Obispito Bay (only $20 \%$ ) probably contributed to the high frequency of $H$. helianthus on high surfaces at this location. In most cases the proportions of urchins and the 2 predatory sea stars on high and low surfaces did not correspond to the availability of these surfaces ( $p<0.0001$; Fig. 1$)$. The exceptions were urchins at El Francés Bay and $H$. helianthus at Obispito Bay, where proportions corresponded to availability.

In the experiments in which we placed predatory sea stars on boulder tops (without urchins) and observed their positions 5 min later, $50 \%$ of the Heliaster helianthus remained on the boulder tops and $50 \%$ moved to the bottom. In contrast, in the parallel trials with Meyenaster gelatinosus only 5\% stayed on the boulder tops and $95 \%$ moved to the bottom. Studies involving long-term ( $>5 \mathrm{~min}$ ) responses by sea stars are needed to estimate the 


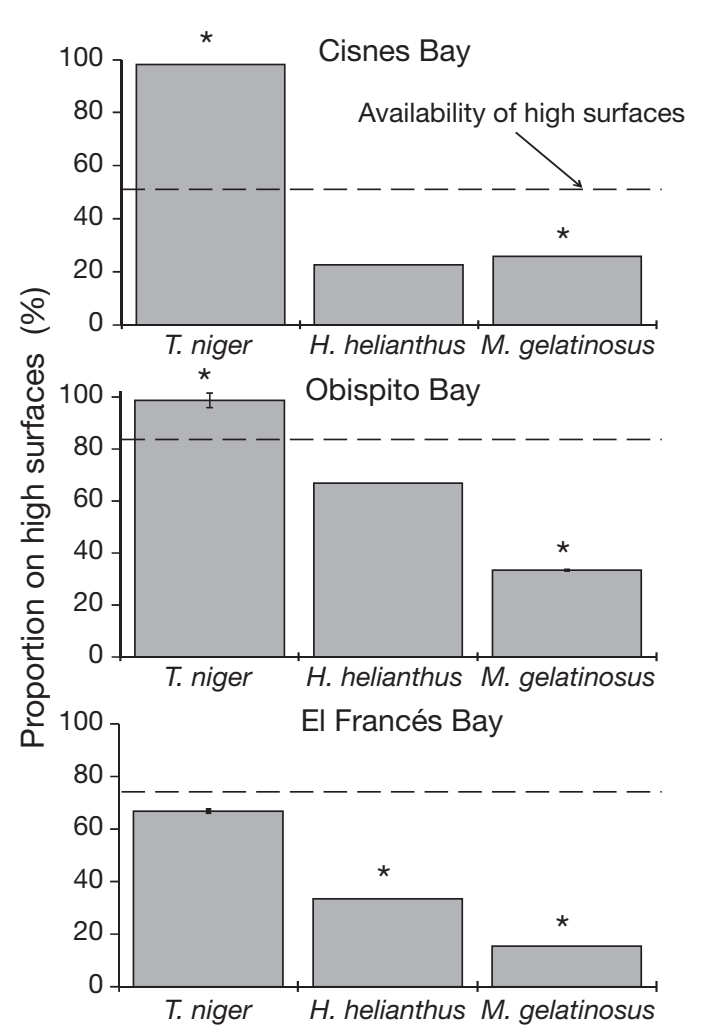

Fig. 1. Mean $( \pm \mathrm{SE})$ proportion $(\%)$ of sea urchin Tetrapygus niger and predatory sea stars Heliaster helianthus and Meyenaster gelatinosus found on high surfaces relative to the availability of high surfaces (dashed lines) at Cisnes, Obispito and El Francés Bays. The entire cove was surveyed at Cisnes Bay (thus SEs are not given), whereas quadrats were sampled at the other bays. *Significant difference between the proportion of high surfaces used and that available $(\mathrm{p}<0.0001)$

effects of them being manipulated. Probably M. gelatinosus was more active or responsive to physical manipulation than $H$. helianthus. Field experiments with $H$. helianthus showed slight differences in displacement between manipulated and nonmanipulated individuals in the first $5 \mathrm{~h}$ following the manipulation but after $9 \mathrm{~h}$ the displacement was similar (Barahona \& Navarrete 2010).

\section{Responses of sea urchins to sea stars on different types of bottom}

On all 3 types of bottoms, the urchins first responded to simulated attacks by raising their spines, and then moved away in the opposite direction to the point of contact with the predator (these responses are described in greater detail in Urriago et al. 2011). The time for the urchins to sever contact with the sea stars did not vary with the sea star predator (Heli-

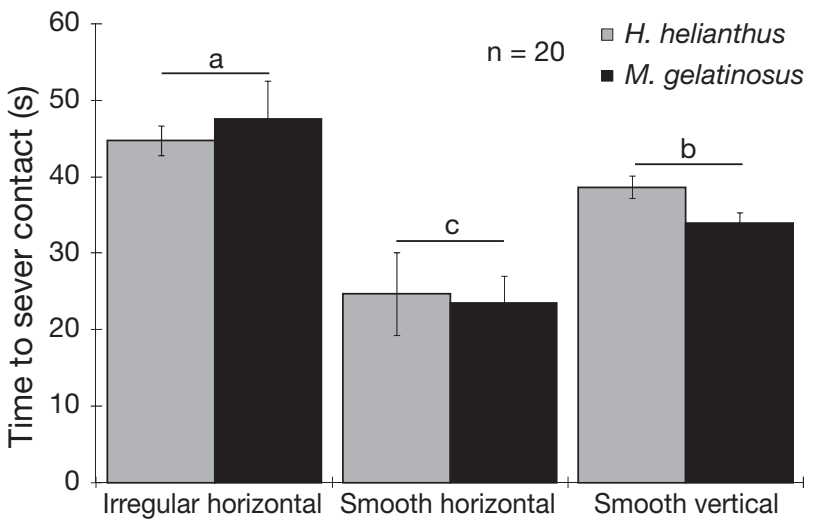

Fig. 2. Tetrapygus niger. Mean $( \pm \mathrm{SE})$ time for the sea urchin ( $\mathrm{n}=20$ per predator per treatment) to sever contact with the predatory sea stars Heliaster helianthus and Meyenaster gelatinosus, on irregular horizontal bottom, smooth horizontal bottom and smooth vertical walls. Different letters indicate significant differences between treatments $(p<0.0001)$. In all treatments, the response did not vary between the 2 sea stars $(p=0.30)$

aster helianthus or Meyenaster gelatinosus) but varied with the type of bottom ( $p<0.0001$; Fig. 2). Contact was severed most rapidly in the trials on smooth horizontal platform (24 s), least rapidly on irregular horizontal bottoms (46 s), and at an intermediate level on relatively smooth vertical walls (36 s).

\section{Sustained (simulated) attacks on vertical walls}

In the trials examining the proportion of urchins detaching when subjected to sustained attacks by predatory sea stars on relatively smooth vertical walls, the target urchin first moved up the wall to distance itself from the sea star. In trials with Heliaster helianthus, $30 \%$ of the urchins detached from the vertical wall before reaching the urchin aggregation at the top. This compared to $75 \%$ of the urchins in the trials with Meyenaster gelatinosus. The targeted urchins that did not detach moved to the edge of the aggregation and almost immediately tried to climb over it. They failed and then moved around the aggregation. Almost all of the urchins in the aggregation at the top moved away a few seconds after the targeted urchin came into contact with the aggregation.

\section{Sustained attacks on aggregations}

The urchin aggregations on boulder tops showed strong escape responses when subjected to sustained attacks by Heliaster helianthus and Meyenaster 


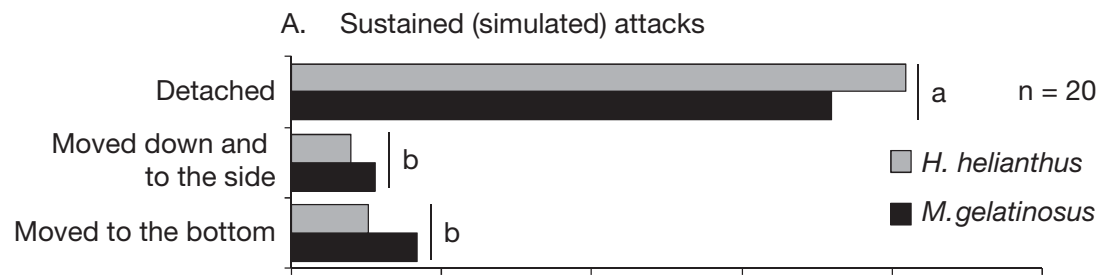

B. 3 min after the sea star was removed

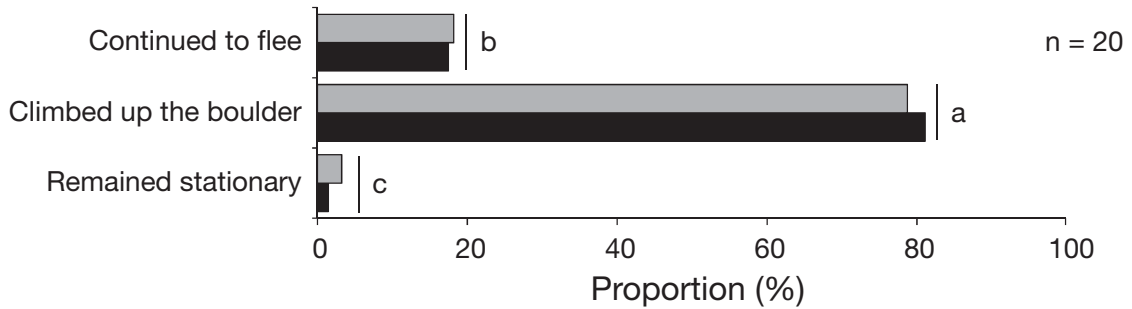

Fig. 3. Tetrapygus niger. Proportion (\%) of urchins ( $\mathrm{n}=20$ per predator per treatment) (A) in aggregations on boulder tops that detached, moved down and to the side or moved to the bottom in response to sustained attacks by the predatory sea stars Heliaster helianthus and Meyenaster gelatinosus, and (B) that continued to flee, climbed up a boulder or remained stationary on the bottom, $3 \mathrm{~min}$ after the predatory sea star was removed. Different letters indicate significant differences between treatments $(\mathrm{p}<0.0001)$ gelatinosus at the edge of the aggregation, and the proportions of urchins in the different behavioural categories (out of the total number of urchins on the boulder tops) did not vary with the sea star species (Fig. 3, p = 0.16). In the trials with both sea star species, all targeted urchins fled in the opposite direction and soon after detached. These represented $82 \%$ of the urchins on the boulder tops in the trials with $H$. helianthus and $72 \%$ in the trials with $M$. gelatinosus. Nearby urchins that did not have contact with the sea stars did not detach but moved away and eventually either (1) moved down and then to the opposite side of the boulder or (2) moved all the way down to the bottom. The proportions of urchins in the latter 2 categories did not vary between trials with the 2 sea stars ( $p=0.21$, Fig. 3).

Following the removal of the predatory sea stars, most of the urchins ( $80 \%$, including individuals that had moved to the sides of the boulders during the attacks) climbed back up the sides of the experimental boulder or an adjacent boulder. Only about 18\% continued to flee and about $2 \%$ remained stationary (Fig. 3). These proportions did not vary between trials with the 2 sea stars $(p=0.62)$.

\section{Survival on high and low surfaces}

The $24 \mathrm{~h}$ trials with tethered sea urchins indicated that survival was $36 \%$ higher on boulder tops than on the bottom for both small and large urchins $(\mathrm{p}=0.01$; Fig. 4). Although the proportion of individuals lost tended to be higher for small than large urchins, the difference was not significant $(p=0.11)$. When we returned at the end of the $24 \mathrm{~h}$ trials, we observed 4 types of predators attacking the urchins: (1) the sea stars Heliaster helianthus and Meyenaster gelatinosus, (2) the blennid fish Scartichthys viridis, (3) the gastropods Tegula atra and Crassilabrum crassilabrum, and (4) hermit crabs Pagurus spp. (Fig. 5). The blennid fish was not observed killing tethered

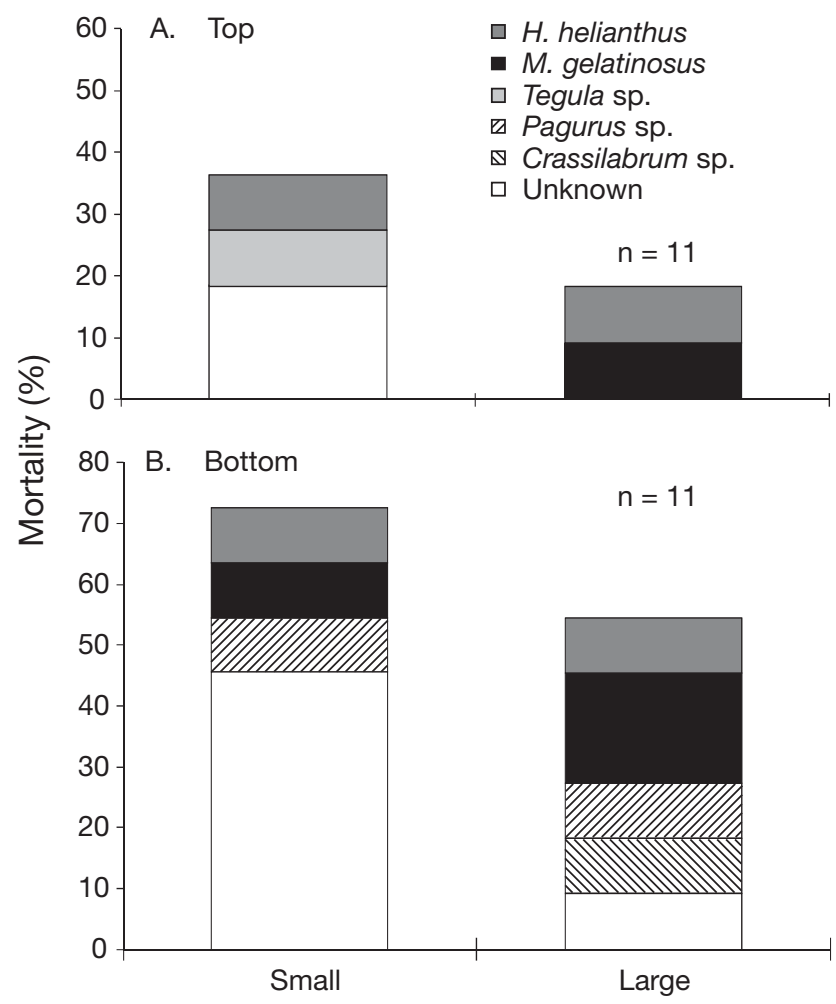

Fig. 4. Tetrapygus niger. Mortality rates inflicted on sea urchins by various predators observed during 24 -h tethering experiments using small (15 to $20 \mathrm{~mm}$ ) and large (50 to 60 $\mathrm{mm}$ ) urchins ( $\mathrm{n}=11$ per size per treatment) on (A) boulder tops or (B) the bottom. Mortality did not vary with urchin size (small vs. large; $p=0.11$ ), but did with position (boulder tops vs. bottom; $\mathrm{p}=0.01$ ) 

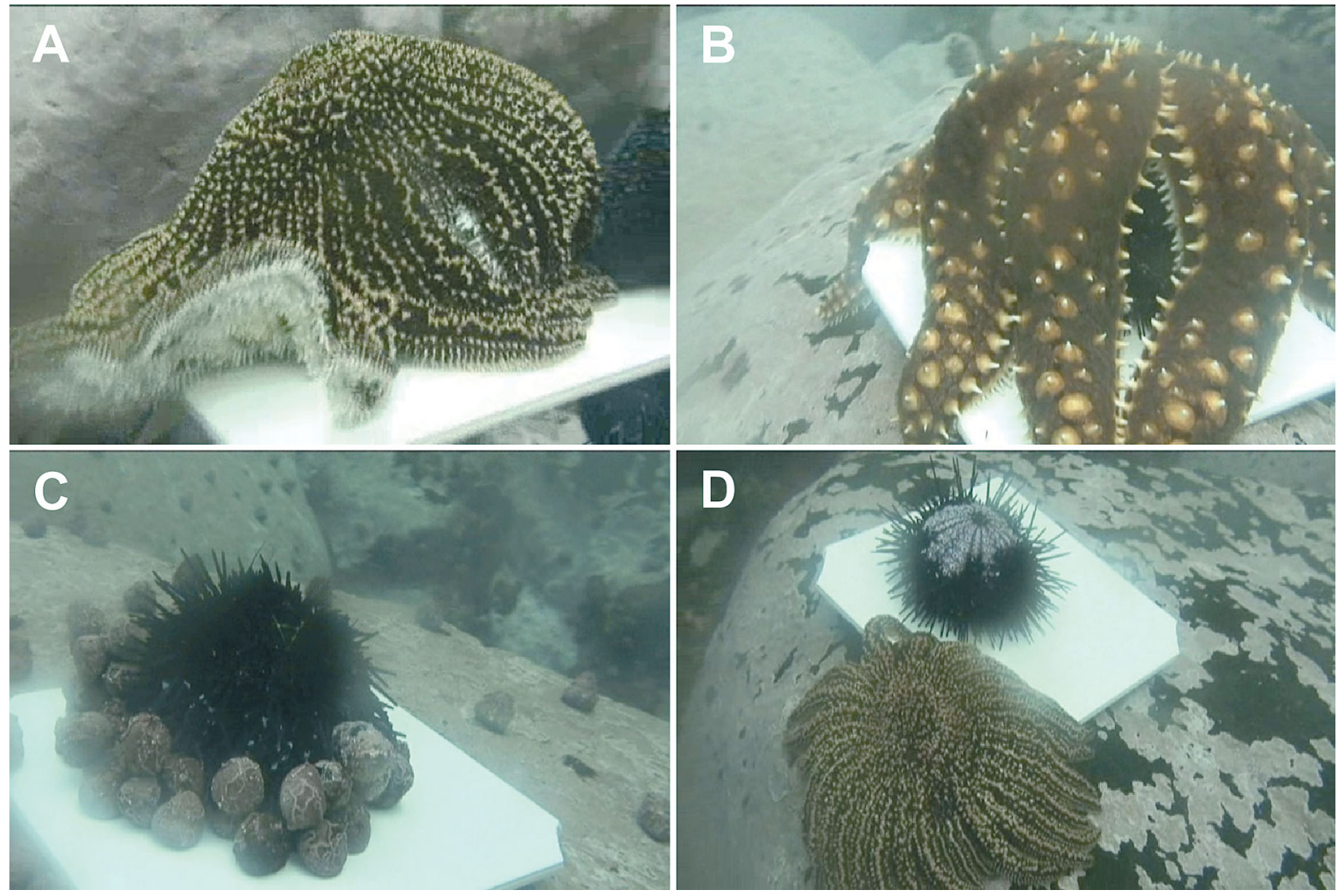

Fig. 5. Predatory attacks on tethered sea urchins Tetrapygus niger. (A) Sea star Heliaster helianthus; (B) sea star Meyenaster gelatinosus; (C) gastropods Tegula atra and Crassilabrum crassilabrum, and hermit crabs Pagurus spp.; and (D) an urchin showing loss of aboral spines, probably due to attacks by the blennid fish Scartichthys viridis (such attacks were observed but not depicted here)

urchins but was seen biting off podia and probably also pedicellaria. All attacks by sea stars were by single individuals that everted their stomach over the urchin, whereas the gastropods and the hermit crabs always attacked in groups, and sometimes both snails and hermit crabs attacked at the same time (they aggregated around the edge of the urchin). We were unable to identify the predators causing many of the attacks on small urchins (labeled unknown in Fig. 4) because the attacks were rapid and there were no prey remains (no tethered urchins escaped in control trials in enclosures). After the $24 \mathrm{~h}$ trials, a number of the urchins were observed with missing spines (the scars appeared as white spots) that we suspect were the result of fish attacks.

\section{DISCUSSION}

Our quantitative survey in 3 bays showed that the sea urchin Tetrapygus niger mostly occurs on elevated surfaces. Almost all the urchins at Cisnes Bay $(98 \%)$ and Obispito Bay $(99 \%)$ and a large propor- tion of urchins at El Francés Bay (67\%) were found on elevated surfaces. During previous dives in northern Chile to observe barrens communities, where the substratum was boulders and bedrock outcrops, we also noted the association of urchins with elevated surfaces (authors' pers. obs.).

Our study provided several lines of evidence indicating that urchins on elevated surfaces are less exposed to risk of attacks by predators. First, elevated surfaces correspond to habitats where the important urchin predators, the sea stars Heliaster helianthus and Meyenaster gelatinosus, occur in reduced numbers. For example, our survey at the 3 bays showed that these 2 sea stars were predominantly $(>75 \%)$ found on lower surfaces, although there was an exception for $H$. helianthus at Obispito Bay, where low surfaces were rare. The preference of sea stars, particularly M. gelatinosus, for bottom surfaces may be related to the risk of being detached by wave action. The probability of falling is likely to increase when sea stars are attacking urchins, as they are less securely attached and arms raised over urchins are more exposed to waves. The sensitivity of 
H. helianthus to wave action was shown by Barahona \& Navarrete (2010) as they observed that its movement in the intertidal zone was reduced when there was increased wave action. We found that both $M$. gelatinosus and $H$. helianthus were more common on low surfaces than on elevated surfaces, but $H$. helianthus tended to use elevated surfaces more than M. gelatinosus (Fig. 1). In the trials in which we placed the 2 sea stars on boulder tops, only $50 \%$ of the $H$. helianthus moved off the boulder tops within 5 min, compared to $95 \%$ for $M$. gelatinosus. $H$. helianthus may be better adapted to wave-swept areas than $M$. gelatinosus because of its many arms and more flattened body (Gaymer \& Himmelman 2008). The high frequency of Tetrapygus niger on elevated surfaces suggests that it is well adapted to wave activity. The urchin usually keeps its spines lowered giving it a flattened profile that should limit the impact of waves.

A second factor that may lead Tetrapygus niger to prefer to aggregate on elevated surfaces is that there are usually fewer irregularities in the substratum than on bottom surfaces (J. D. Urriago pers. obs.). Irregularities caused by pebbles, shell debris and small cobbles as well as crevices can block the urchin from fleeing from sea stars. For example, in our trials with simulated attacks on individuals, the urchins needed almost twice as much time to sever contact with a sea star on an irregular horizontal bottom than on a smooth horizontal bottom. Sea stars readily move over bottom irregularities because of their large size and extended arms, whereas urchins must follow the contours of small depressions and ridges. On 3 occasions during dives we observed an urchin fleeing from Meyenaster gelatinosus that became trapped in a crevice. In each instance the sea star climbed onto the urchin, wrapping its arms around it to begin feeding. Our diving observations of interactions between urchins and sea stars suggest that it is unlikely that Heliaster helianthus and M. gelatinosus can catch $T$. niger on smooth surfaces where the urchin's movement is unimpeded. Similarly Dayton et al. (1977) observed that the urchin Loxechinus albus must be blocked by bottom irregularities for attacks of $M$. gelatinosus to be successful. In our trials involving sustained attacks of urchin aggregations on boulder tops, most urchins that had detached or moved down to the bottom climbed up the sides of the boulders once the sea stars were removed. The return to the boulder tops in the absence of the sea star suggests that this behaviour would reduce the risk of attack by sea stars. Phillips $(1975,1976)$ found that the gastropods Acmaea spp. climbed vertical surfaces when they detected the odour (without contact) of predatory sea stars (Pisaster ochraceus, Pisaster giganteus, Pycnopodia helianthoides, and Leptasterias aequalis). This contrasts with $T$. niger which moves to elevated surfaces even when there is no predatory stimulus.

A third advantage of elevated surfaces is that they provide the urchin with the alternative of detaching from the substratum ('jumping ship') to avoid being eaten. This was seen when we made sustained attacks (1) on individual urchins on vertical walls and (2) on urchin aggregations on boulder tops. Detachment caused the urchins to fall and be transported by wave surge, thus rapidly distancing them from the sea stars. Although this behaviour of 'jumping ship' prevents urchins from being eaten, it entails costs. Spines are likely broken, so that energy must be expended for spine repair (Ebert 1968, Edwards \& Ebert 1991). Further, urchins usually land on the bottom 'oralside-up' and must extend podia to right themselves. During our experiments we often observed the blennid fish Scartichthys viridis biting the podia of urchins that were righting themselves after falling from walls. $S$. viridis feeds manly on algae (Ojeda \& Munoz 1999, Muñoz \& Ojeda 2000), but Dumont et al. (2011) recently showed that $S$. viridis is an aggressive omnivore that also preys on the tunicates Pyura chilensis and Ciona intestinalis. If an urchin were unlucky enough to fall near another sea star, it would have to right itself before it would be able to flee. The urchin likely only resorts to detaching when the risk of predation is extreme. This was indicated because the urchins simply fled in response to being subjected to a simulated attack, whereas they almost always detached when subjected to a sustained simulated attack (trials on vertical walls and boulder tops). Other prey species have also been reported to detach from the bottom to avoid predatory attacks. For example, laboratory studies by Alexander \& Covich (1991) show that the gastropod Physella virgata detaches from the bottom and floats upward when touched by predatory crayfish. When Heliaster helianthus encounters Meyenaster gelatinosus, which is also its predator, it suddenly raises its arms ('crown position'). This involves detachment from the bottom, making it more likely to be transported by wave action (Gaymer \& Himmelman 2008). Snyder \& Snyder (1970) exposed urchins Diadema antillarum to odours of injured conspecifics under a strong unidirectional flow and observed that individuals lost hold on the substratum 
and were carried by the current, providing another example of an animal detaching in response to a perceived risk. Finally, diving observations by Dayton et al. (1977) showed that various prey species detach and fall to the bottom when they detect the odour of $M$. gelatinosus. Thus, detachment and use of water flow may be a common strategy used to limit predatory attacks.

Our trials with tethered urchins provided strong evidence that survival is greater on high than low surfaces but there was no statistical difference in survival between small (15 to $20 \mathrm{~mm}$ ) and large urchins (50 to $60 \mathrm{~mm}$ ). About half of the predators that could be identified during these trials were sea stars. In contrast, Rodriguez \& Ojeda (1998) noted that during laboratory trials Meyenaster gelatinosus pass over small urchins (20 to $30 \mathrm{~mm}$ ) without causing damage, preferring to attack large urchins (35 to $60 \mathrm{~mm}$ ). Observations of prey-size selection of feeding sea stars encountered during an extensive benthic survey (Gaymer 2006) showed that the most common size group of urchins (individuals measuring 40 to $60 \mathrm{~mm}$ in diameter) was eaten $62 \%$ of the time by M. gelatinosus and $65 \%$ of the time for Heliaster helianthus. In their survey the sizes of urchins consumed by $M$. gelatinosus closely reflected availability, whereas $H$. helianthus tended to select smaller urchins. Although tethering undoubtedly reduces the ability of urchins to escape from predators, this technique nevertheless provides a tool for identifying predators and comparing levels of predation in different habitats (Shears \& Babcock 2002, Guidetti \& Dulcic 2007). We observed a variety of animals feeding on $T$. niger that have not previously been reported to prey on urchins. These included the blennid fish Scartichthys viridis, the gastropods Tegula atra and Crassilabrum crassilabrum, and hermit crabs Pagurus spp.

Meyenaster gelatinosus likely represents a greater predatory threat to Tetrapygus niger than Heliaster helianthus; urchins subjected to sustained attacks (extreme predation risk) on vertical walls detached $45 \%$ more often when the sea star predator was M. gelatinosus than when it was $H$. helianthus. Further, M. gelatinosus preferentially feeds on the urchin (Gaymer \& Himmelman 2008). In contrast $H$. helianthus is a generalist feeder that most frequently consumes mussels, barnacles and small gastropods (Barahona \& Navarrete 2010). Responses of T. niger to the 2 sea star species provide further evidence that M. gelatinosus represents a stronger threat than $H$. helianthus; the urchin severs contact faster with $M$. gelatinosus than with $H$. helianthus when subjected to simulated attacks, and the urchin detects M. gelatinosus at greater distances than $H$. helianthus (Urriago et al. 2011).

Many studies report that the distribution of urchins is related to the distribution of their foods, for example urchins often form grazing fronts at the edge of kelp beds or aggregate on algal debris that has been carried by currents to urchin barrens (Vadas et al. 1986, Himmelman \& Nedelec 1990, Scheibling \& Hamm 1991, Hagen \& Mann 1994, Vadas \& Elner 2003). Field observations by Rodriguez \& Fariña (2001) similarly indicate that Tetrapygus niger aggregates on drift kelp Macrocystis pyrifera, and Rodriguez \& Ojeda (1998) found that T. niger aggregated on drift algae Lessonia sp. added to experimental tanks. It is thus unlikely that the microdistribution of $T$. niger on elevated surfaces is related to food resources, because food is rare on elevated surfaces. Boulder tops are devoid of fleshy algae and any macroalgal debris present usually sinks to depressions in the bottom.

Tetrapygus niger aggregates on elevated surfaces and moves to higher surfaces even when not being pursued by a sea star. The present study indicates that this choice of microhabitat represents an adaptation for avoiding being eaten by 2 common predatory sea stars. Occupying elevated surfaces might increase exposure to pelagic predators such as fish. Predation in tethering experiments on other species of urchins (small to medium sizes) is higher at locations where the density of predatory fish is high than in areas where it is low (Sala \& Zabala 1996, Shears \& Babcock 2002, Guidetti 2006). In Chile, the abundance of fish predators of $T$. niger is presently low because of overfishing (Godoy et al. 2010). Thus, the decrease in fish predators may have led to increased numbers of urchins on elevated surfaces and an increase in the importance of the sea stars Heliaster helianthus and Meyenaster gelatinosus as predators of urchins. Bonaviri et al. (2009) similarly suggest that a decrease in numbers of predatory fish (Diplodus sargus and D. vulgaris) may have increased the importance of the sea star Marthasterias glacialis in controlling the abundance of the urchins in the Mediterranean Sea. Additional studies are needed to further understand the effects of predators on the distribution and abundance of $T$. niger. It would be particularly useful to use continuous videoing of tethered urchins to document the types of predators that attack urchins during different periods of the day. Such studies would at the same time indicate whether there are predators that have not hitherto been observed. 
Acknowledgements. We are grateful to E. Renaud-Roy and M. N. Muñoz for their extensive help during the field work. L. Harvey also helped in the field work. The paper was further improved by comments from C. P. Dumont, H. E. Guderley, L. E. Johnson, H. M. Feder, J. W. Qiu and 3 anonymous reviewers. The study was funded by a National Sciences and Engineering Council (NSERC) grant to J.H.H. and a Fondo Nacional de Desarrollo Científico y Tecnológico (Fondecyt) grant to C.F.G. J.D.U. received financial support from Quebec-Ocean and Centro de Estudios Avanzados en Zonas Áridas. H. Crépaud provided statistical support.

\section{LITERATURE CITED}

Alcoverro T, Mariani S (2002) Effects of sea urchin grazing on seagrass (Thalassodendron ciliatum) beds of a Kenyan lagoon. Mar Ecol Prog Ser 226:255-263

> Alexander JE, Covich AP (1991) Predator avoidance by the freshwater snail Physella virgata in response to the crayfish Procambarus simulans. Oecologia 87:435-442

> Andrew NL, MacDiarmid AB (1991) Interrelations between sea urchins and spiny lobsters in northeastern New Zealand. Mar Ecol Prog Ser 70:211-222

- Barahona M, Navarrete SA (2010) Movement patterns of the seastar Heliaster helianthus in central Chile: relationship with environmental conditions and prey availability. Mar Biol 157:647-661

Barrios JV, Gaymer CF, Vasquez JA, Brokordt KB (2008) Effect of the degree of autotomy on feeding, growth, and reproductive capacity in the multi-armed sea star Heliaster helianthus. J Exp Mar Biol Ecol 361:21-27

Bonaviri C, Vega Fernández T, Badalamenti F, Gianguzza P, Di Lorenzo M, Riggio S (2009) Fish versus starfish predation in controlling sea urchin populations in Mediterranean rocky shores. Mar Ecol Prog Ser 382:129-138

Caro T (2005) Antipredator defenses in birds and mammals, Chicago University Press, Chicago, IL

Chivers DP, Smith RJF (1998) Chemical alarm signalling in aquatic predator-prey systems: a review and prospectus. Ecoscience 5:338-352

> Dayton PK, Rosenthal RJ, Mahen LC, Antezana T (1977) Population structure and foraging biology of predaceous Chilean asteroid Meyenaster gelatinosus and escape biology of its prey. Mar Biol 39:361-370

> Dumont CP, Gaymer CF, Thiel M (2011) Predation contributes to invasion resistance of benthic communities against the non-indigenous tunicate Ciona intestinalis. Biol Invas 13:2023-2034

- Ebert TA (1968) Growth rates of the sea urchin Strongylocentrotus purpuratus related to food availability and spine abrasion. Ecology 49:1075-1091

Edwards PB, Ebert TA (1991) Plastic responses to limited food availability and spine damage in the sea urchin Strongylocentrotus purpuratus (Stimpson). J Exp Mar Biol Ecol 145:205-220

Estes JA, Tinker MT, Williams TM, Doak DF (1998) Killer whale predation on sea otters linking oceanic and nearshore ecosystems. Science 282:473-476

Fuentes HR (1981) Feeding habit of Semicossyphus maculatus (Labridae) in coastal waters of Iquique in northern Chile. Jpn J Ichthyol 27:309-315

Fuentes HR (1982) Feeding habits of Graus nigra (Labridae) in coastal waters of Iquique in northern Chile. Jpn J
Ichthyol 29:95-98

Gaymer CF (2006) Coexistencia y función de los asteroídeos en las comunidades submareales rocosas del norte de Chile, proyecto Fondecyt 3030007. CONICYT, Santiago, Chile

Gaymer CF, Himmelman JH (2008) A keystone predatory sea star in the intertidal zone is controlled by a higherorder predatory sea star in the subtidal zone. Mar Ecol Prog Ser 370:143-153

Godoy N, Gelcich S, Vasquez JA, Castilla JC (2010) Spearfishing to depletion: evidence from temperate reef fishes in Chile. Ecol Appl 20:1504-1511

Guidetti P (2006) Marine reserves reestablish lost predatory interactions and cause community changes in rocky reefs. Ecol Appl 16:963-976

Guidetti P, Dulcic J (2007) Relationships among predatory fish, sea urchins and barrens in Mediterranean rocky reefs across a latitudinal gradient. Mar Environ Res 63:168-184

Hagen NT, Mann KH (1994) Experimental analysis of factors influencing the aggregating behavior of the green sea urchin Strongylocentrotus droebachiensis (Müller). J Exp Mar Biol Ecol 176:107-126

Hagen N, Andersen $\AA$, Stabell OB (2002) Alarm responses of the green sea urchin, Strongylocentrotus droebachiensis, induced by chemically labelled durophagous predators and simulated acts of predation. Mar Biol 140:365-374

> Hereu B, Zabala M, Linares C, Sala E (2005) The effects of predator abundance and habitat structural complexity on survival of juvenile sea urchins. Mar Biol 146:293-299

- Himmelman JH, Dutil C (1991) Distribution, population structure and feeding of subtidal seastars in the northern Gulf of St. Lawrence. Mar Ecol Prog Ser 76:61-72

Himmelman JH, Nedelec H (1990) Urchin foraging and algal survival strategies in intensely grazed communities in eastern Canada. Can J Fish Aquat Sci 47:1011-1026

Himmelman JH, Cardinal A, Bourget E (1983) Community development following removal of urchins, Strongylocentrotus droebachiensis, from the rocky subtidal zone of the St. Lawrence Estuary, eastern Canada. Oecologia 59: 27-39

Jensen M (1966) The response of two sea-urchins to the sea-star Marthasterias glacialis (L.) and other stimuli. Ophelia 3:209-219

> Legault C, Himmelman JH (1993) Relation between escape behaviour of benthic marine invertebrates and the risk of predation. J Exp Mar Biol Ecol 170:55-74

> Lima SL, Dill LM (1990) Behavioral decisions made under the risk of predation: a review and prospectus. Can J Zool 68:619-640

McClanahan TR, Shafir SH (1990) Causes and consequences of sea urchin abundance and diversity in Kenyan coral reef lagoons. Oecologia 83:362-370

Medina M, Araya M, Vega C (2004) Feeding and trophic relationships of coastal fish off northern Chile. Invest Mar 32:33-47 (in Spanish with English abstract)

> Moitoza DJ, Phillips DW (1979) Prey defense, predator preference, and nonrandom diet: the interactions between Pycnopodia helianthoides and two species of sea urchins. Mar Biol 53:299-304

> Muñoz AA, Ojeda FP (2000) Ontogenetic changes in the diet of the herbivorous Scartichthys viridis in a rocky intertidal zone in central Chile. J Fish Biol 56:986-998

Navarrete SA, Manzur T (2008) Individual- and populationlevel responses of a keystone predator to geographic 
variation in prey. Ecology 89:2005-2018

Ojeda FP, Muñoz AA (1999) Feeding selectivity of the herbivorous fish Scartichthys viridis: effects on macroalgal community structure in a temperate rocky intertidal coastal zone. Mar Ecol Prog Ser 184:219-229

Phillips DW (1975) Distance chemoreception-triggered avoidance behavior of the limpets Acmaea (Collisella) limatula and Acmaea (Notoacmea) scutum to the predatory starfish Pisaster ochraceus. J Exp Zool 191:199-209

Phillips DW (1976) The effect of a species-specific avoidance response to predatory starfish on the intertidal distribution of two gastropods. Oecologia 23:83-94

Rodriguez SR, Fariña JM (2001) Effect of drift kelp on the spatial distribution pattern of the sea urchin Tetrapygus niger: a geostatistical approach. J Mar Biol Assoc UK 81:179-180

Rodríguez SR, Ojeda FP (1993) Distribution patterns of Tetrapygus niger (Echinodermata: Echinoidea) off the central Chilean coast. Mar Ecol Prog Ser 101:157-162

Rodríguez SR, Ojeda FP (1998) Behavioral responses of the sea urchin Tetrapygus niger to predators and food. Mar Freshw Behav Physiol 31:21-37

Rosenthal RJ, Chess JR (1972) A predator-prey relationship between the leather star, Dermasterias imbricata, and the purple urchin, Strongylocentrotus purpuratus. Fish Bull 70:205-216

Ruxton GD, Sherratt TN, Speed MP (2004) Avoiding attack. The evolutionary ecology of crypsis, warning signals and mimicry, Oxford University Press, Oxford

Sala E (1997) Fish predators and scavengers of the sea urchin Paracentrotus lividus in protected areas of the north-west Mediterranean Sea. Mar Biol 129:531-539

Sala E, Zabala M (1996) Fish predation and the structure of the sea urchin Paracentrotus lividus populations in the NW Mediterranean. Mar Ecol Prog Ser 140:71-81

Sala E, Ribes M, Hereu B, Zabala M, Alvà V, Coma R, Garrabou J (1998) Temporal variability in abundance of the sea urchins Paracentrotus lividus and Arbacia lixula in the northwestern Mediterranean: comparison between a marine reserve and an unprotected area. Mar Ecol Prog Ser 168:135-145

Saporito RA, Donnelly MA, Garraffo HM, Spande TF, Daly JW (2006) Geographic and seasonal variation in alkaloid-based chemical defenses of Dendrobates pumilio from Bocas del Toro, Panama. J Chem Ecol 32:795-814

SAS Institute (2008) SAS/STAT ${ }^{\circledR} 9.2$ User's Guide. SAS Institute, Cary, NC

Editorial responsibility: James McClintock,

Birmingham, Alabama, USA
Scheibling RE, Hamm J (1991) Interactions between sea urchins (Strongylocentrotus droebachiensis) and their predators in field and laboratory experiments. Mar Biol 110:105-116

> Shears NT, Babcock RC (2002) Marine reserves demonstrate top-down control of community structure on temperate reefs. Oecologia 132:131-142

Sih A, Crowley P, McPeek M, Petranka J, Strohmeier K (1985) Predation, competition, and prey communities: a review of field experiments. Annu Rev Ecol Syst 16: 269-311

Snedecor GW, Cochran WG (1989) Statistical methods, 8th edn. Iowa State University Press, Ames, IA

Snyder N, Snyder H (1970) Alarm response of Diadema antillarum. Science 168:276-278

Tegner MJ, Levin LA (1983) Spiny lobsters and sea urchins: analysis of a predator-prey interaction. J Exp Mar Biol Ecol 73:125-150

Tokeshi M, Estrella C, Paredes C (1989) Feeding ecology of a size-structured predator population, the South American sun-star Heliaster helianthus. Mar Biol 100:495-505

> Tuya F, Boyra A, Sanchez-Jerez P, Barbera C, Haroun RJ (2004) Relationships between rocky-reef fish assemblages, the sea urchin Diadema antillarum and macroalgae throughout the Canarian Archipelago. Mar Ecol Prog Ser 278:157-169

> Urriago JD, Himmelman JH, Gaymer CF (2011) Responses of the black sea urchin Tetrapygus niger to its sea-star predators Heliaster helianthus and Meyenaster gelatinosus under field conditions. J Exp Mar Biol Ecol 399: $17-24$

- Vadas RL, Elner RW (2003) Responses to predation cues and food in two species of sympatric, tropical sea urchins. PSZN I: Mar Ecol 24:101-121

> Vadas RL, Elner RW, Garwood PE, Babb IG (1986) Experimental evaluation of aggregation behavior in the sea urchin Strongylocentrotus droebachiensis. A reinterpretation. Mar Biol 90:433-448

Vasquez JA, Buschmann AH (1997) Herbivore-kelp interactions in Chilean subtidal communities: a review. Rev Chil Hist Nat 70:41-52

Vega JMA, Vasquez JA, Buschmann AH (2005) Population biology of the subtidal kelps Macrocystis integrifolia and Lessonia trabeculata (Laminariales, Phaeophyceae) in an upwelling ecosystem of northern Chile: interannual variability and El Niño 1997-1998. Rev Chil Hist Nat 78: 33-50

Submitted: April 15, 2011; Accepted: September 12, 2011 Proofs received from author(s): December 30, 2011 